Scientific Paper

Doi: http://dx.doi.org/10.1590/1809-4430-Eng.Agric.v42n1e20210084/2022

\title{
FUZZY MODELING OF THE EFFECT OF IRRIGATION DEPTHS ON BEET CULTIVARS
}

\author{
Luís R. A. Gabriel Filho ${ }^{*}$, Alexsandro O. da Silva ${ }^{2}$, \\ Camila Pires Cremasco ${ }^{1}$, Fernando Ferrari Putti ${ }^{1}$
}

\author{
${ }^{1 *}$ Corresponding author. São Paulo State University (UNESP)/ Tupã - SP, Brazil. \\ E-mail: gabriel.filho@unesp.br | ORCID ID: http://orcid.org/0000-0002-7269-2806
}

\section{KEYWORDS}

water deficit, production, fuzzy logic, beet, artificial intelligence.

\begin{abstract}
The objective of this study was to develop a Fuzzy Rule-Based System (FRBS) for the mathematically modeling of the irrigation level effect on beet cultivars (Beta vulgaris L.). From an agronomic experiment carried out in a protected environment (greenhouse), it was defined as input variables, for each cultivar, the irrigation levels (depths of 25, 40, $55,70,85$, and $100 \%$ of ETc), in which ETc is the crop evapotranspiration $\left[\mathrm{mm} \mathrm{d}^{-1}\right]$, while the output variables were productivity, root diameter, and plant height. Was adopted the inference method of Mamdani and centroid method for fuzzification. The fuzzy models performed better than polynomial regression models, when compared with the coefficients of determination $\left(\mathrm{R}^{2}\right)$, mean absolute error (MAE) and root mean square error (RMSE). In addition, the excellent performance of the model is highlighted due to the curve containing all the points of the treatments means. As agronomic results, concluded that the Early Wonder cultivar has higher yields when submitted to water deficit.
\end{abstract}

\section{INTRODUCTION}

Currently (2019), the water crisis in Brazil has caused a shortage of water for irrigation. In this sense, many farmers have reduced the water volume applied. Therefore, there is a need to use cultivars resistant to water stress (Hussain et al., 2019).

Beet is one of the most used vegetables in salads and juices. In Brazil, the state of São Paulo is one of the major consumers (Lauterbach et al., 2019). It can be grown as a crop, used as forage for cattle feeding, or as a source of sugar, the latter mostly in Europe (Maitah et al., 2016).

Irrigation levels vary with crop traits, weather conditions, and soil types. These factors, therefore, must be considered in irrigation water management to optimize yield (Mukherjee, 2017; López-Mata et al., 2019). Ideal conditions for beet growth occur in winter, as lower temperatures favour its development (Gobin, 2018). According to the same author, the winter in Southeastern Brazil is characterized by lower rainfall, therefore lower soil moisture and lower crop production.
The occurrence of water deficit in vegetables compromises the productivity and quality due to the short cycle and high-water content in their composition (Ilic \& Fallik, 2017). Therefore, any occurrence of water stress can lead to low income and losses in production (Lesk et al., 2016, Jalava et al., 2016). In the State of São Paulo, Brazil, the period of lowest rainfall occurs between the months of may to august, period in that the planting of vegetables should be done using irrigation to reach adequate levels of productivity (Silva et al., 2015). However, the lack of capital for assembling irrigation systems by small producers can have consequences in the production of vegetables due to the availability of water in the soil. This problem should be reduced by the selection of drought tolerant crops; these crops are able to support periods of water shortage during the planting (Nuccio et al., 2018).

In this regard, Prato (2012) used a fuzzy system to analyze the resistance capacity of protected natural areas at the detriment of climate change. And with the advances of prolonged droughts, Giusti \& Marsili-Libelli (2015), applying the fuzzy theory, developed a model to determine the ideal water replacement rate and thus optimize the water

\footnotetext{
${ }^{1}$ São Paulo State University (UNESP)/ Tupã - SP, Brazil.

${ }^{2}$ Federal University of Ceará (UFC)/ Fortaleza - CE, Brazil.

Area Editor: Fernando França da Cunha

Received in: 6-1-2021

Accepted in: 11-23-2021
} 
resources of the region. So, we can highlight many applications, using fuzzy models, impact on corn planting (Waongo et al., 2014), orchids management (Putti et al., 2014), evaluation of lettuce indicators submitted to irrigation with magnetic water and water deficit (Putti, et al., 2015).

When used for data modelling, the fuzzy systems adopted here as an artificial intelligence system are notoriously more accurate than polynomial regression models. This is because the techniques adopted to build them seek to obtain the best approximations of means established by the levels of experimental tests of the treatments. Other models can also obtain results with similar precision, but the behaviour of the system makes its choice not to be overlooked. Behaviours such as the appearance of negative values or magnitudes much higher than the one expected by the model. Thus, not only the excellent accuracy of the model but also the expected behaviour of the model, make the fuzzy systems very suitable for mathematical modelling in agricultural sciences. Finally, also highlighting the benefits of such systems, the rule base generated by such models (with Mamdani's inference method) allows easy interpretation of the model by rural producers.

The present study aimed to develop a Fuzzy RuleBased System (FRBS) to mathematically model the effect of irrigation levels on beet cultivars and establish implicit rules for agronomic experiments. Thus, this study aimed to develop a system using artificial intelligence (fuzzy logic) to model mathematically the effect of irrigation levels on beet cultivars (Beta vulgaris L.).

\section{MATERIAL AND METHODS}

\section{Experiment Description}

To elaborate a Fuzzy Rule-Based System (FRBS), one agronomic experiment was carried out at the College of Agricultural Sciences of the São Paulo State University (UNESP), campus in Botucatu-SP, Brazil. Treatments consisted of six irrigation levels or depths $(25,40,55,70$, 85 , and $100 \%$ ETc) applied via drip irrigation and based on crop evapotranspiration (ETc), as well as two beet cultivars (Early Wonder and Itapuã 202).

The experiment was carried out in $15 \mathrm{~L}$ vases with a randomized block design $(2 \times 6)$, with four replications, totaling 48 experimental plots. The seedlings were prepared in trays containing 128 cells, constantly irrigated until they reach three true leaves, at the moment of transplanting. In the first 10 Days After the Transplanting (DAT), the seedlings were normally irrigated without differentiation of the levels in order to establish them, after the beginning of treatments.

Reference evapotranspiration (ETo) was calculated using a Class A evaporation pan, with daily evaporation readings (ETo), according to the following equation:

$$
E T o=E C A \times K p,
$$

Where:

ETo is the reference evapotranspiration $\left(\mathrm{mm} \cdot \mathrm{day}^{-1}\right)$; $E C A$ is the "class A" pan evaporation $\left(\mathrm{mm}^{\mathrm{day}}{ }^{-1}\right)$, and $K p$ is the "class A" pan evaporation coefficient. For greenhouse conditions, we used a $K p=1.0$, as recommended by Elvanidi et al. (2017) (Figure 1).

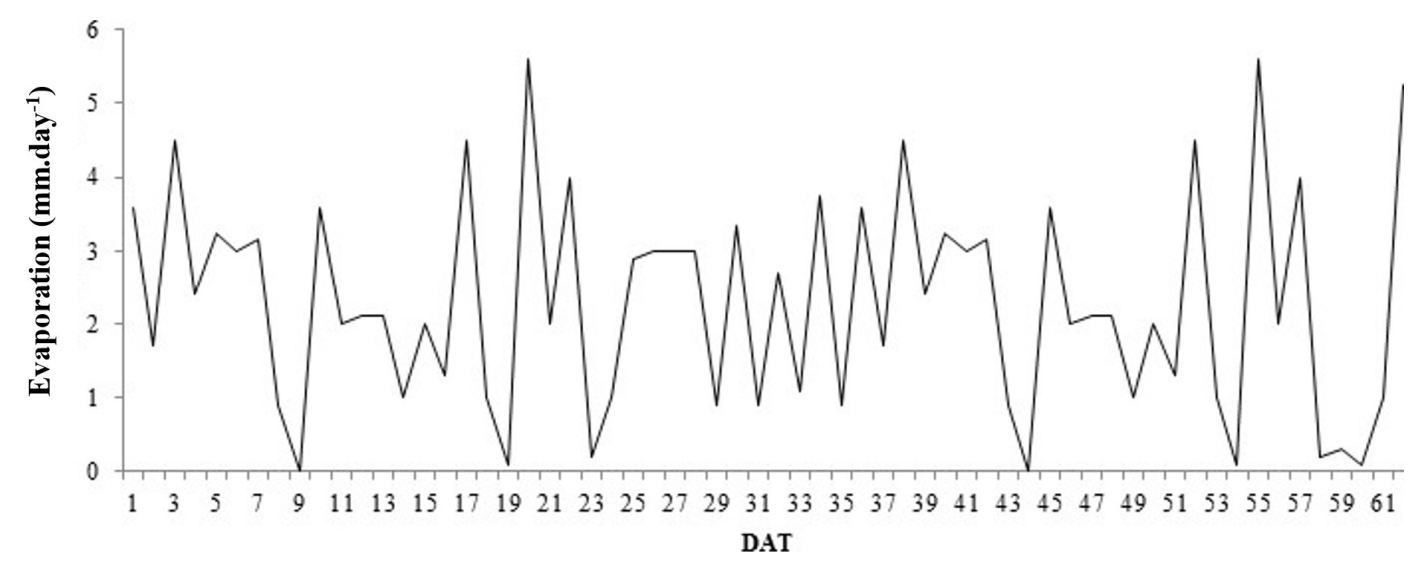

FIGURE 1. Daily evaporation in the greenhouse during the experiment.

Crop evaporation was determined using the crop coefficient $(K c)$ according to Doorenbos \& Pruitt (1997), fractionating the applied depths as a function of the treatment, as the following equation:

$$
E T c=E T o \times K c \times f,
$$

Where:

ETC is the crop evapotranspiration $\left[\mathrm{mm}_{\mathrm{day}}{ }^{-1}\right]$;

ETo is the reference evapotranspiration $\left[\mathrm{mm} \cdot \mathrm{day}^{-1}\right]$;

$K c$ is the crop coefficient [-], and

$f$ is the fraction of irrigation to be applied [\%], namely $25,40,55,70,85,100 \%$.
Table 1 shows the amount of water applied to the crop according to each treatment. Drip irrigation efficiency was deemed 90\% (Keller \& Bliesner, 2000).

TABLE 1. Amount of water applied in the beet crop and its value of ETc, according to each irrigation level [mm] (treatment) considered.

\begin{tabular}{ccc}
\hline Treatments & Irrigation $[\mathrm{mm}]$ & ETc $[\mathrm{mm}]$ \\
\hline $25 \%$ & 33.23 & 29.91 \\
$40 \%$ & 50.17 & 45.15 \\
$55 \%$ & 61.05 & 54.94 \\
$70 \%$ & 68.38 & 61.55 \\
$85 \%$ & 74.65 & 67.18 \\
$100 \%$ & 97.23 & 87.51 \\
\hline
\end{tabular}


At the time that the harvest was realized at $61 \mathrm{DAT}$, a $0.001 \mathrm{~g}$ precision scale was used for the measurement of Green Root Phytomass (GRP) [g], and digital pachymeter for measuring the Root Diameter (RD) [mm] and Plant Height (PH) [cm].

\section{Fuzzy Rule-Based System (FRBS)}

An input processor (or fuzzification), a set of linguistic rules, a method of fuzzy inference, and an output processor (or defuzzification) were defined to build the FRBS, generating a real number as output (Figure 2).

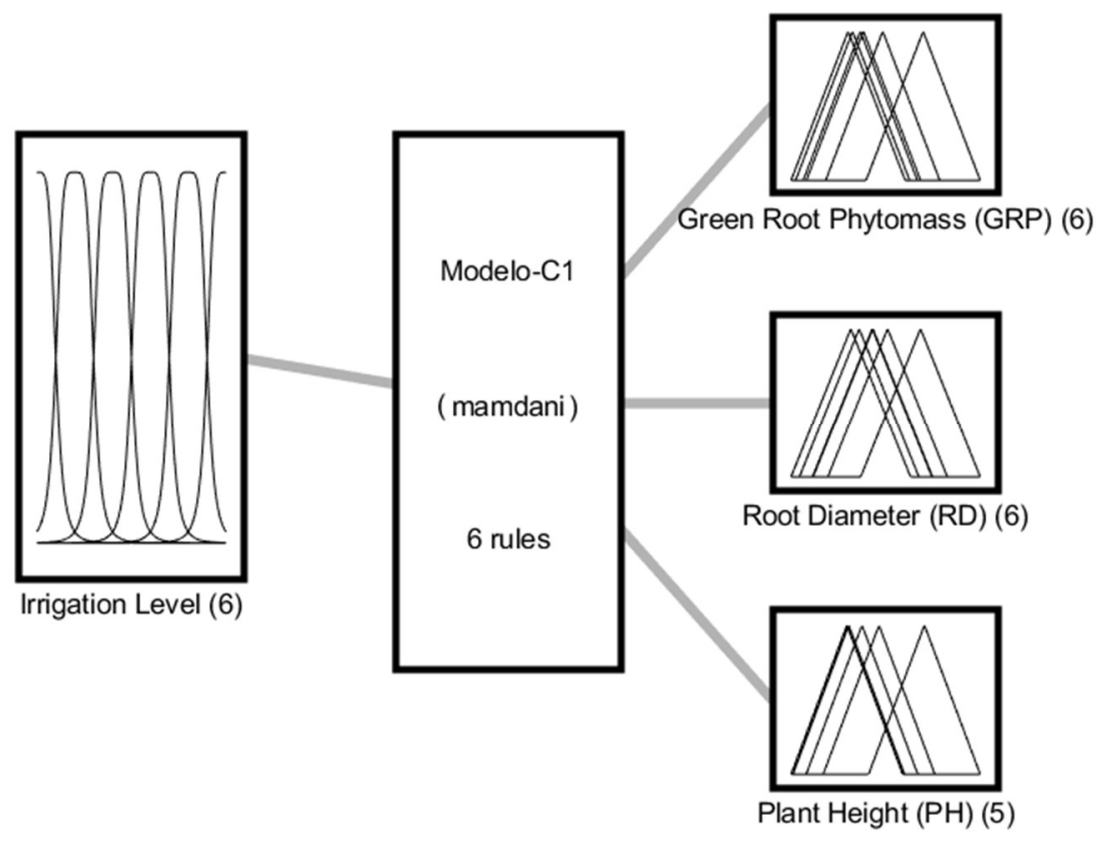

FIGURE 2. Fuzzy Rule-Based Systems proposed for the mathematical modeling of irrigation levels effect in beet cultivars (Beta Vulgaris L.) fwith 1 input variable (Irrigation Level), 3 output variables (Green Root Phytomass, Root Diameter and Plant Height) and 6 rules.

Two FRBS were built, one for each cultivar (Early Wonder and Itapuã 202), each represented by the following function:

$F:[0,100] \rightarrow \mathbb{R}^{3}, \quad F(x)=\left(f_{1}(x), f_{2}(x), f_{3}(x)\right)$

Where:

The domain $[0,100]$ represents the Irrigation Levels (\% of ETc). The codomain $\mathbb{R}^{3}$ represents the three response variables evaluated, namely: green root phytomass (GRP), root diameter $(\mathrm{RD})$, and plant height $(\mathrm{PH})$. The results are shown in 3 two-dimensional plots, each one showing one output variable and with two curves (two cultivars).

To develop an input processor, fuzzy sets of input variables (Irrigation Level - $L$ ) were established. Thereby, six fuzzy sets $\left(C_{i}, 1 \leq i \leq 6\right)$ were defined according to the six irrigation levels estimated by ETc rates, namely $(10+15 i) \%, 1 \leq i \leq 6$.

The membership functions of these fuzzy input sets used in the model were of the Generalized bell-shaped membership function type (The MathWorks, 2021), defined as:

$$
f(x)=\frac{1}{1+\left|\frac{x-c}{a}\right|^{2 b}}
$$

Where:

$a$ : defines the width of the membership function, where a larger value creates a wider membership function;

$b$ : defines the shape of the curve on either side of the central plateau, where a larger value creates a more steep transition,

$c$ : defines the center of the membership function.

Thus, the values of parameter $c$ were all defined by $(10+15 i), 1 \leq i \leq 6$, for each fuzzy set $C_{i}$. For the determination of the other parameters $a$ and $b$, a transformation process of a membership function originally defined as a triangular shape (Figure 3A) was used and then converted to the Generalized bell-shaped form (Figure 3B). Thus, considering the parameters $\left[k_{1}^{i} k_{2}^{i} k_{3}^{i}\right]$ of the triangular membership function of the fuzzy set $C_{i}, 1 \leq i \leq$ 6, we adopted:

$$
\begin{gathered}
k_{2}^{i}=(10+15 i), 1 \leq i \leq 6 \\
k_{1}^{1}=10, k_{3}^{6}=115 \\
k_{1}^{i}=k_{2}^{i-1}, 2 \leq i \leq 6 \\
k_{3}^{i}=k_{2}^{i+1}, 1 \leq i \leq 5
\end{gathered}
$$




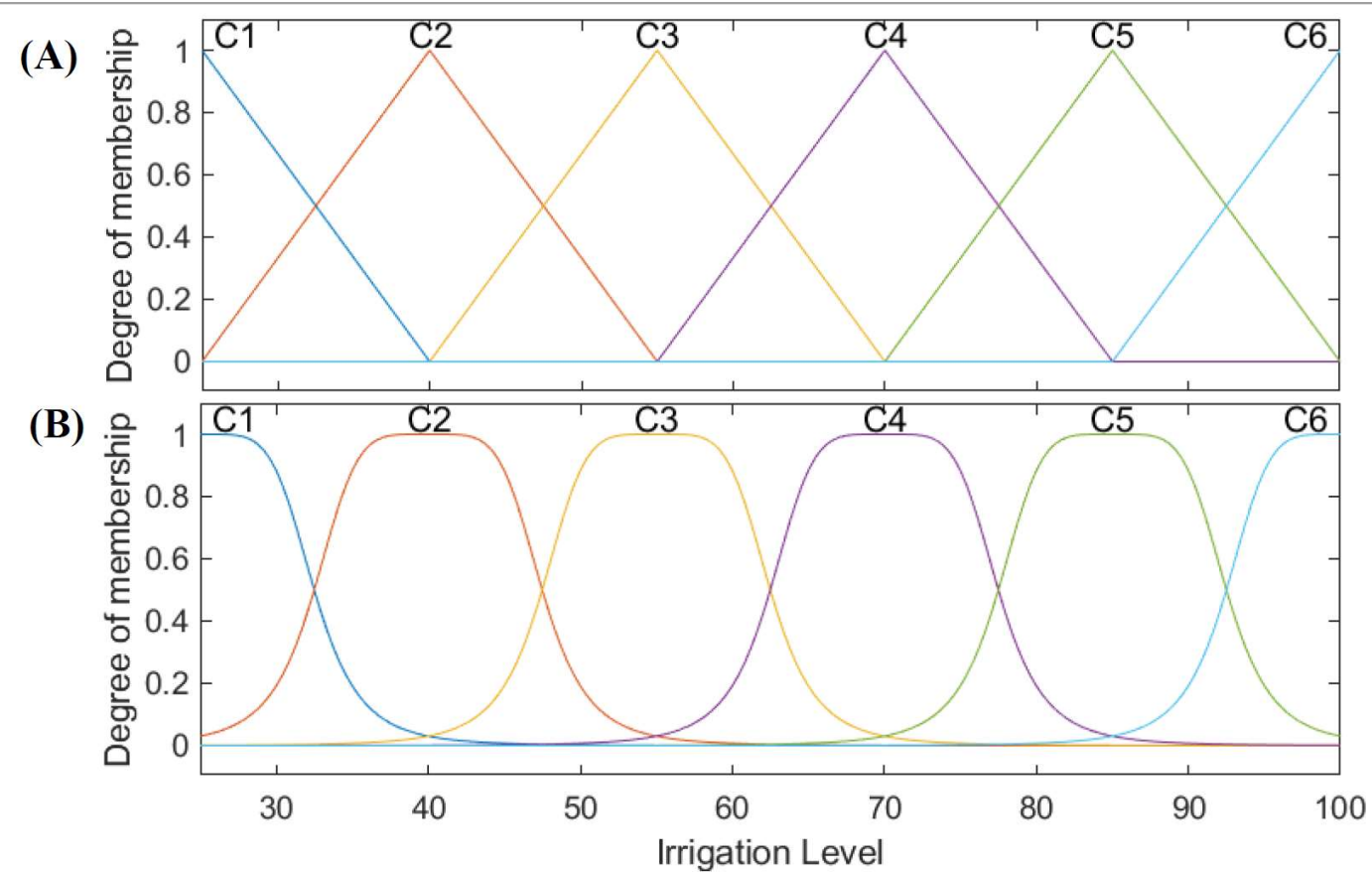

FIGURE 3. Membership functions of input fuzzy sets $\boldsymbol{C}_{\boldsymbol{i}}, \mathbf{1} \leq \boldsymbol{i} \leq \mathbf{6}$, of the Irrigation Level in the range [0, 100], originally defined as a (A) Triangular shape, and posteriorly converted to the (B) Generalized bell-shaped form.

The conversion of the parameters of the triangular functions $\left[k_{1} k_{2} k_{3}\right]$ to the parameters of the Generalized bell-shaped functions $[a b c]$ (Table 2), was done using the following procedure obtained from the function "Translate parameters between membership functions", identified by

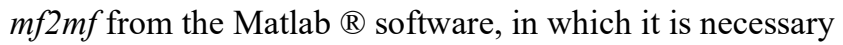
to define intermediate parameters $p_{1}, p_{2}, q_{1}, q_{2}$ :

$$
\begin{gathered}
p_{1}=0.5\left(k_{2}-k_{1}\right)+k_{1} \\
q_{1}=0.9\left(k_{2}-k_{1}\right)+k_{1} \\
q_{2}=0.1\left(k_{3}-k_{2}\right)+k_{2} \\
p_{2}=0.5\left(k_{3}-k_{2}\right)+k_{2} \\
c=\frac{q_{2}+q_{1}}{2} \\
a=c-p_{1} \\
b=\frac{2 a}{q_{1}-p_{1}}
\end{gathered}
$$

\begin{tabular}{|c|c|c|}
\hline Fuzzy Set & Type & Parameters \\
\hline$C_{1}$ & Generalized bell & {$\left[\begin{array}{lll}7.5 & 2.5 & 25\end{array}\right]$} \\
\hline$C_{2}$ & Generalized bell & {$\left[\begin{array}{lll}7.5 & 2.5 & 40\end{array}\right]$} \\
\hline$C_{3}$ & Generalized bell & 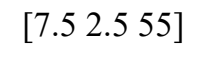 \\
\hline$C_{4}$ & Generalized bell & {$\left[\begin{array}{lll}7.5 & 2.5 & 70\end{array}\right]$} \\
\hline$C_{5}$ & Generalized bell & {$\left[\begin{array}{lll}7.5 & 2.5 & 85\end{array}\right]$} \\
\hline$C_{6}$ & Generalized bell & {$\left[\begin{array}{lll}7.5 & 2.5 & 100\end{array}\right]$} \\
\hline
\end{tabular}

TABLE 2. Parameters of Generalized bell-shaped membership functions of $\boldsymbol{C}_{\boldsymbol{i}}, \mathbf{1} \leq \boldsymbol{i} \leq \mathbf{6}$ fuzzy sets of Irrigation Level input variable.
It is noteworthy that the generated value of $c$ generated by this procedure is equivalent to that previously defined by the rates of ETc $(10+15 i) \%, 1 \leq i \leq 6$. In fact, simplifying notations:

$$
\begin{gathered}
k_{2}=10+15 i \\
k_{1}=10+15(i-1) \Rightarrow k_{1}=15 i-5 \\
k_{3}=10+15(i+1) \Rightarrow k_{3}=15 i+25 \\
p_{1}=0.5\left(k_{2}-k_{1}\right)+k_{1}=0.5(15)+15 i-5 \Rightarrow p_{1}=15 i+2.5 \\
q_{1}=0.9\left(k_{2}-k_{1}\right)+k_{1}=0.9(15)+15 i-5 \Rightarrow q_{1}=15 i+8.5 \\
q_{2}=0.1\left(k_{3}-k_{2}\right)+k_{2}=0.1(15)+10+15 i \Rightarrow q_{2}=15 i+11.5 \\
p_{2}=0.5\left(k_{3}-k_{2}\right)+k_{2}=0.5(15)+10+15 i \Rightarrow p_{2}=15 i+17.5 \\
c=\frac{q_{2}+q_{1}}{2} \Rightarrow c=10+15 i \\
a=c-p_{1} \Rightarrow a=7.5 \\
b=\frac{2 a}{q_{1}-p_{1}}=\frac{15}{6} \Rightarrow b=2.5
\end{gathered}
$$

And so, the parameters of each input membership function $C_{i}, 1 \leq i \leq 6$, of type Generalized bell-shaped, are given by $[a b c]=\left[\begin{array}{lll}7.5 & 2.5 & (10+15 i)\end{array}\right]$.

As there were 6 input fuzzy sets, six rules were adopted for the composition of the rule-base for both proposed models (one model for each cultivar). Thus, each rule associates an input fuzzy set with 3 fuzzy sets, each belonging to a different output variable.

The statistical design adopted was a $2 \times 6$ factorial ( 2 cultivars and 6 irrigation depths). The average of 3 output variables of the 6 treatments was obtained for each cultivar, and an ANOVA was performed with subsequent application of the Tukey's test (or Tukey's honestly significant difference test). In this test, the value of the minimum significant difference $(\Delta)$ is obtained, wherein treatment 
means will be considered significantly different only if the distance between them is greater than $\Delta$.

The means of the 6 treatments of each variable in each cultivar were calculated, and the number $n$ of distinct means was identified, with $n \leq 6$. Subsequently, such means are sorted in ascending order and denoted as follows $m_{1}<m_{2}<\cdots m_{n}$, associating them with $\mathrm{n}$ fuzzy sets $C_{1}, C_{2}, \ldots, C_{n}$, whose triangular membership functions have the following parameters (Figure 4):

$$
\left[\left(m_{i}-\Delta\right) m_{i}\left(m_{i}+\Delta\right)\right], \quad 1 \leq i \leq n
$$

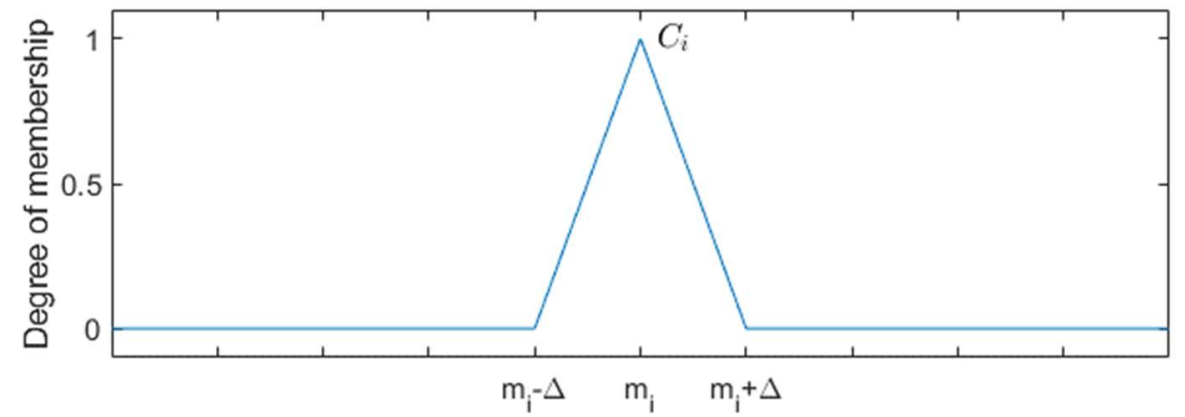

FIGURE 4. Generic membership function of the output variables using the minimum significant difference $(\Delta)$ of the Tukey's test.

The rule-base formed by the 6 rules was structured by associating the six treatments $(\mathrm{L})$ with their respective means. This association has been extended to the respective fuzzy input and output sets. Thus, the fuzzy sets $C_{i}$ of the input variable, $1 \leq i \leq 6$, were associated with the fuzzy sets $C_{j}$ of the output variables, $1 \leq j \leq n$, with these last sets being created from the means of experimental treatments. This methodology was used similarly by Cremasco et al. (2010), Gabriel Filho et al. (2011, 2015, 2016), Pereira et al. (2008), Putti et al. (2014, 2017a, 2017b, 2021), Viais Neto et al. (2019a, 2019b), Martínez et al. (2020), Matulovic et al. (2021), Góes et al. (2021), Boso et al. (2021a, 2021b), and Maziero et al. (2022).

The inference method used to calculate the numerical value of the output variables, according to the rules base, was from Mamdani (Mamdani \& Assilian, 1975).
According Barros et al. (2017), Mamdani proposed, a binary fuzzy relation $\mathcal{M}$ between $x$ and $u$ to mathematically model the rule base. The Mamdani method is based on the inference composition rule max-min according to the following procedure:

- $\quad$ Each rule $R_{j}$ from the fuzzy rule base, the conditional "if $x$ is $A_{j}$ then $u$ is $B_{j}$ " is modeled by the operation $\wedge$ (minimum);

- $\quad$ It uses the $\mathrm{t}$-norm $\wedge$ (minimum) for the logical conective "and";

- $\quad$ For the logical connective "or" the t-conorm $\mathrm{V}$ (maximum) is adopted that connects the fuzzy rules of the rule base.

Formally, the fuzzy relation $\mathcal{M}$ is the fuzzy subset of $X \times U$ whose membership function is given by:

$$
\varphi_{\mathcal{M}}(x, u)=\max _{1 \leq j \leq r}\left(\varphi_{R_{j}}(x, u)\right)=\max _{1 \leq j \leq r}\left[\varphi_{A_{j}}(x) \wedge \varphi_{B_{j}}(u)\right]
$$

Where:

$r$ is the number of rules that compose the rule base and, $A_{j}$ and $B_{j}$ are the fuzzy subsets of the rule $j$. Each one of the values $\varphi_{A_{j}}(x)$ and $\varphi_{B_{i}}(u)$ is interpreted as the degree that $x$ and $u$ are in the fuzzy subsets $A_{j}$ and $B_{j}$, respectively. Thus, $\mathcal{M}$ is nothing more than the union of the fuzzy Cartesian products between the antecedents and the consequents of each rule.
As an example, Barros et al. (2017) propose a fuzzy system with two inputs and a single output, whose rule base is given by:

$$
\begin{aligned}
& \text { - } R_{1} \text { : If } x_{1} \text { is } A_{11} \text { and } x_{2} \text { is } A_{12} \text { then } u \text { is } B_{1} \text {; or } \\
& \text { - } R_{2} \text { : If } x_{1} \text { is } A_{21} \text { and } x_{2} \text { is } A_{22} \text { then } u \text { is } B_{2} \text {. }
\end{aligned}
$$

Now, for a given fuzzy set with input $A=A_{1} \times A_{2}$, where $A_{1}$ and $A_{2}$ are two fuzzy numbers, the output fuzzy set, which represents the control to be adopted for $A$ by the Mamdani method, is given by $B=\mathcal{M}^{\circ} A$, whose membership function is:

$$
\varphi_{B}(u)=\varphi_{\mathcal{M}^{\circ} A}(u)=\sup _{x}\left[\varphi_{\mathcal{M}}(x, u) \wedge \varphi_{A}(x)\right]=\varphi_{B_{R_{1}}}(u) \vee \varphi_{B_{R_{2}}}(u)
$$

Where:

$B_{R_{1}}$ and $B_{R_{2}}$ are the partial outputs due to the rules $R_{1}$ and $R_{2}$, respectively.

According to Barros et al. (2017), is possible to observe by (4) that the output from the Mamdani method results from the union between the partial outputs of each rule. To obtain each partial output, we proceed in the following manner by the same author. Perform an intersection of each input with each antecedent of the rule and next, calculate the Cartesian product (distinct universes) of these intersections with the rule consequents. The projection of this Cartesian product onto the space $U$ is the partial output for the fuzzy set of input $A$. Graphically we have Figure 5, and the general output is given by the union of the partial outputs according to Figure 6. 

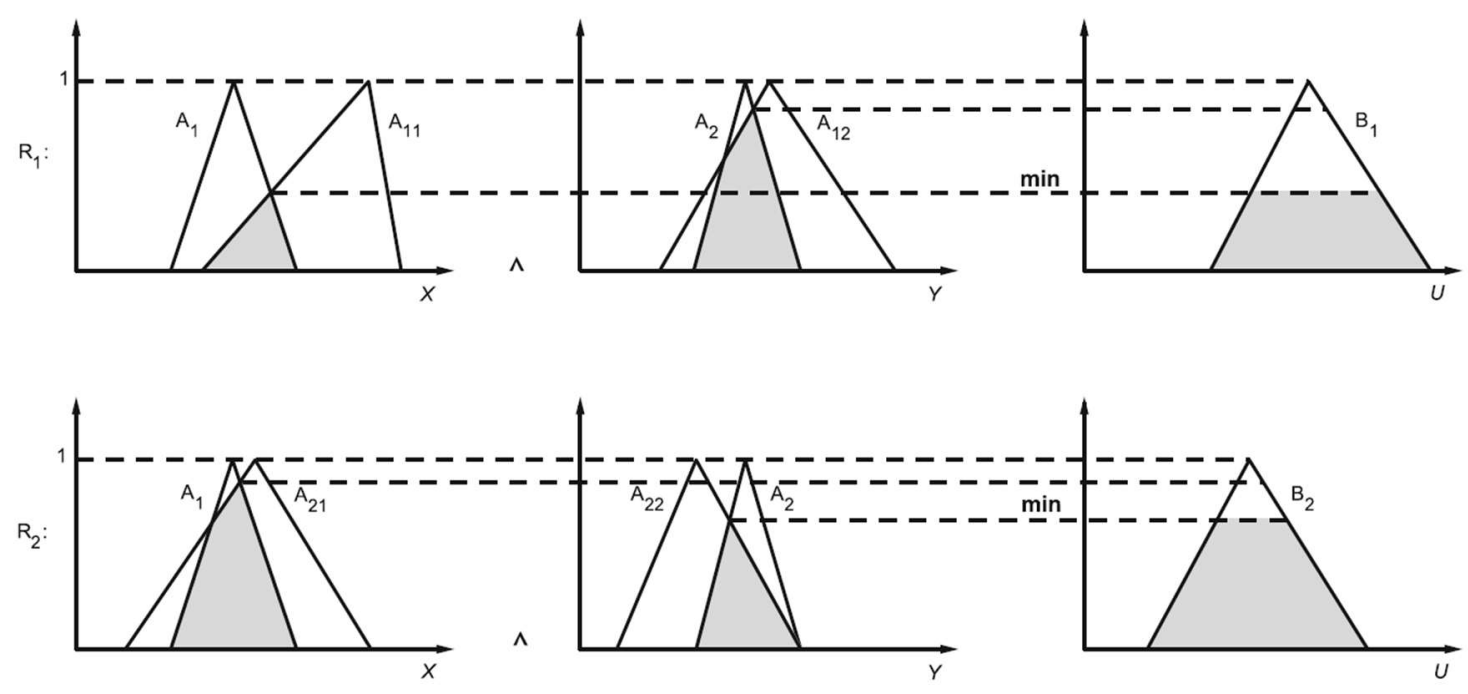

FIGURE 5. Partial outputs in the Mamdani method (Barros et al., 2017).

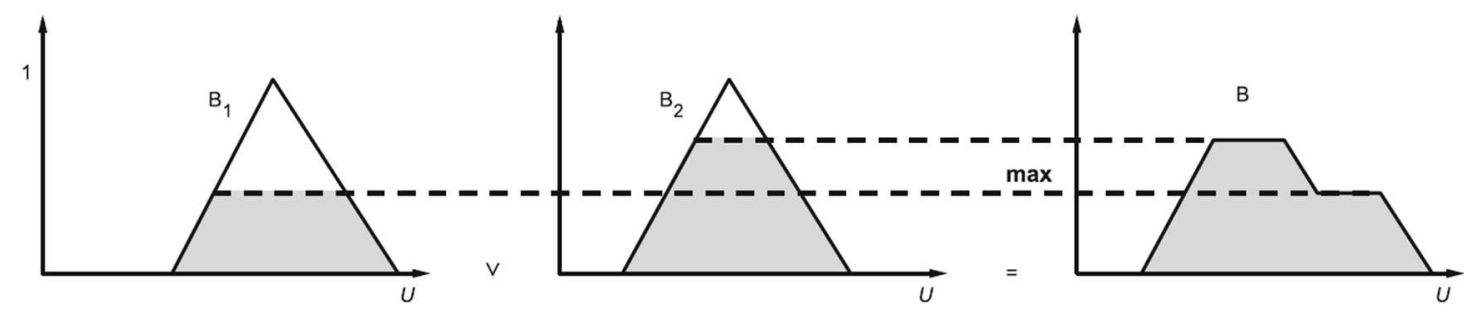

FIGURE 6. Final output of the Mamdani method (Barros et al., 2017).

A multivariate cluster analysis was performed to determine the similarity among observations of each plant. Then, an associated Dendrogram was generated using Complete Linkage and Euclidean distance methods (Table 3 and Figure 7).

TABLE 3. Cluster centroid of multivariate analysis (Cluster Observations) using the Complete Linkage and Euclidean distance methods, for the beet cultivars Early Wonder and Itapuã 202.

\begin{tabular}{|c|c|c|c|c|c|c|c|}
\hline \multirow{2}{*}{ Cultivar } & \multirow{2}{*}{ Variables } & \multicolumn{6}{|c|}{ Clusters } \\
\hline & & 1 & 2 & 3 & 4 & 5 & 6 \\
\hline \multirow{3}{*}{ Early Wonder } & Green Root Phytomass & 158.3 & 210.0 & 108.3 & 280.0 & 21.0 & 54.4 \\
\hline & Plant Diameter & 62.9 & 76.7 & 57.0 & 82.0 & 32.0 & 39.8 \\
\hline & Plant Height & 37.7 & 44.0 & 35.2 & 43.0 & 31.6 & 31.3 \\
\hline \multirow{3}{*}{ Itapuã 202} & Green Root Phytomass & 150.0 & 235.0 & 71.7 & 19.4 & 110.0 & 46.7 \\
\hline & Plant Diameter & 60.2 & 73.7 & 51.4 & 35.6 & 60.6 & 41.4 \\
\hline & Plant Height & 36.8 & 45.0 & 34.7 & 29.4 & 31.0 & 27.8 \\
\hline
\end{tabular}

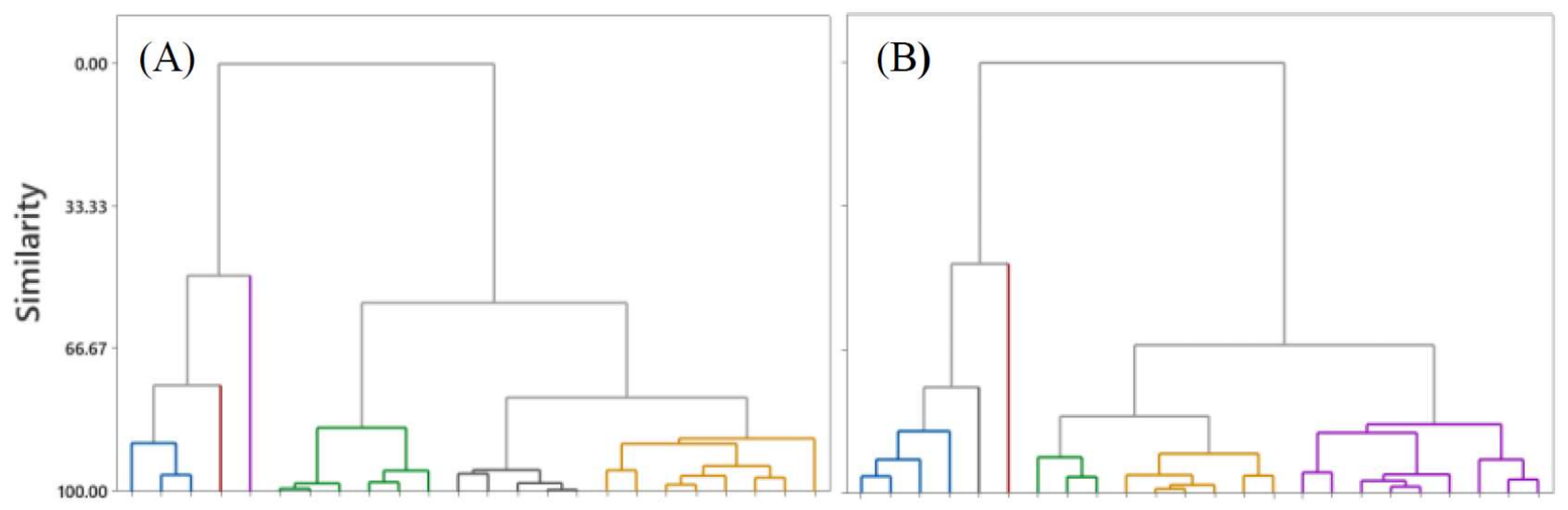

FIGURE 7. Dendrogram generated of the multivariate analysis of the Cluster Observations type which the Complete Linkage and Euclidean distance methods, for the beet cultivars (A) Early Wonder and (B) Itapuã 202. 
Given these methods, and seeking a similarity close to 85 , six clusters were structured at similarity levels of precisely 85.1 and 84.1 for Early Wonder and Itapuã 202 cultivars, respectively. To set delimiters of the fuzzy set membership functions, modelling strategies were adopted, wherein output membership functions represented output treatment means and had amplitude equivalent to the least significant difference $(\Delta)$ by Tukey's test.

A fuzzy logic-based system could be created computationally with the aid of a fuzzy logic toolbox from MATLAB $^{\mathrm{TM}}$ software.

\section{Models Validation}

For the analysis and validation of the fuzzy models efficiency, as well as for the data comparison, we use a polynomial quadratic regression model, which is useful when there is reason to believe that relationship between two variables is curvilinear (Ostertagová, 2012).

After fitting, the models fuzzy and polynomial were evaluated using some of the common indicators used to evaluate the accuracy of a regression model. For this, we use the indicators coefficient of determination $\left(\mathrm{R}^{2}\right)$, root mean square error (RMSE), and mean absolute error (MAE).
The coefficient of determination $\left(\mathrm{R}^{2}\right)$ consists in evaluating the quality of the model's adjustment with the percentage or how much the model was able to explain the data collected experimentally (Ringle et al., 2014). Acoording Boso et al. (2021a), the root mean square error (RMSE) and the mean absolute error (MAE), are measures of uncertainty in the model, where it indicates the size of the error caused by the model. The better the model fits, the smaller the error.

\section{RESULTS AND DISCUSSION}

After calculating their membership functions (Table 4), the output variables could be modelled (Figures 8A, B, C). About 6 fuzzy sets were defined for each output variable since the proposed method aligned with the experimental design adopted. The triangular membership functions were symmetric since the same support $(2 \Delta)$ was adopted for each variable and cultivar, where $\Delta$ is a minimum significant difference of the Tukey's test. The support of a real-valued function is the subset of the domain containing those elements which are not mapped to zero.

TABLE 4. Parameters of membership functions of output variables Green Root Phytomass, Root Diameter and Plant Height of beet submitted to different irrigations levels (\% ETc) for the Early Wonder and Itapuã 202 beet cultivars.

\begin{tabular}{|c|c|c|c|c|}
\hline Cultivar & Fuzzy Set & Green Root Phytomass & Root Diameter & Plant Height \\
\hline \multirow{6}{*}{ Early Wonder } & $C_{1}$ & {$\left[\begin{array}{llll}-67.4 & 43.8 & 154.9\end{array}\right]$} & {$\left[\begin{array}{lllll}7.3 & 36 & 64.7\end{array}\right]$} & [ $\left.\begin{array}{llll}23.6 & 3 & 3 & 38.4\end{array}\right]$ \\
\hline & $C_{2}$ & {$\left[\begin{array}{lll}-58.7 & 52.5 & 163.7\end{array}\right]$} & {$\left[\begin{array}{llll}11 & 1.3 & 40 & 68.7\end{array}\right]$} & {$\left[\begin{array}{llll}23.9 & 31.3 & 38.6\end{array}\right]$} \\
\hline & $C_{3}$ & {$\left[\begin{array}{lll}-43.7 & 67.5 & 178.7\end{array}\right]$} & {$[17.646 .375]$} & [25.6 33 40.4] \\
\hline & $C_{4}$ & {$\left[\begin{array}{lll}-37.4 & 73.8 & 184.9\end{array}\right]$} & {$\left[\begin{array}{llll}17.9 & 46.6 & 75.3\end{array}\right]$} & {$\left[\begin{array}{llll}27.9 & 35.3 & 42.6\end{array}\right]$} \\
\hline & $C_{5}$ & {$\left[\begin{array}{llll}0.1 & 111.3 & 222.4\end{array}\right]$} & {$\left[\begin{array}{lll}25 & 53.7 & 82.4\end{array}\right]$} & [33.9 41.348 .6$]$ \\
\hline & $C_{6}$ & {$\left[\begin{array}{llll}78.9 & 190 & 301.2\end{array}\right]$} & [40.8 69.5 98.2] & - \\
\hline \multirow{6}{*}{ Itapuã 202} & $C_{1}$ & {$\left[\begin{array}{lll}-65.3 & 27.5 & 120.3\end{array}\right]$} & {$\left[\begin{array}{llll}12.6 & 34.9 & 57.3\end{array}\right]$} & {$\left[\begin{array}{lll}13.7 & 26.8 & 39.8\end{array}\right]$} \\
\hline & $C_{2}$ & {$\left[\begin{array}{llll}-61.5 & 31.3 & 124\end{array}\right]$} & {$\left[\begin{array}{llll}13.9 & 36.2 & 58.6\end{array}\right]$} & {$\left[\begin{array}{lll}15.2 & 28.3 & 41.3\end{array}\right]$} \\
\hline & $C_{3}$ & {$\left[\begin{array}{llll}-55.3 & 37.5 & 130.3\end{array}\right]$} & [18.2 40.6 63] & [ $\left.\begin{array}{llll}16.7 & 29.8 & 42.8\end{array}\right]$ \\
\hline & $C_{4}$ & {$\left[\begin{array}{llll}-25.3 & 67.5 & 160.3\end{array}\right]$} & [24.7 4769.4$]$ & [17.4 30.5 43.6] \\
\hline & $C_{5}$ & {$\left[\begin{array}{lll}6.0 & 98.8 & 191.5\end{array}\right]$} & {$\left[\begin{array}{llll}28.6 & 51 & 73.4\end{array}\right]$} & [23.2 36.3 49.3] \\
\hline & $C_{6}$ & {$\left[\begin{array}{llll}59.8 & 152.5 & 245.3\end{array}\right]$} & {$\left[\begin{array}{llll}42.5 & 64.9 & 87.2\end{array}\right]$} & {$\left[\begin{array}{lll}25.2 & 38.3 & 51.3\end{array}\right]$} \\
\hline
\end{tabular}



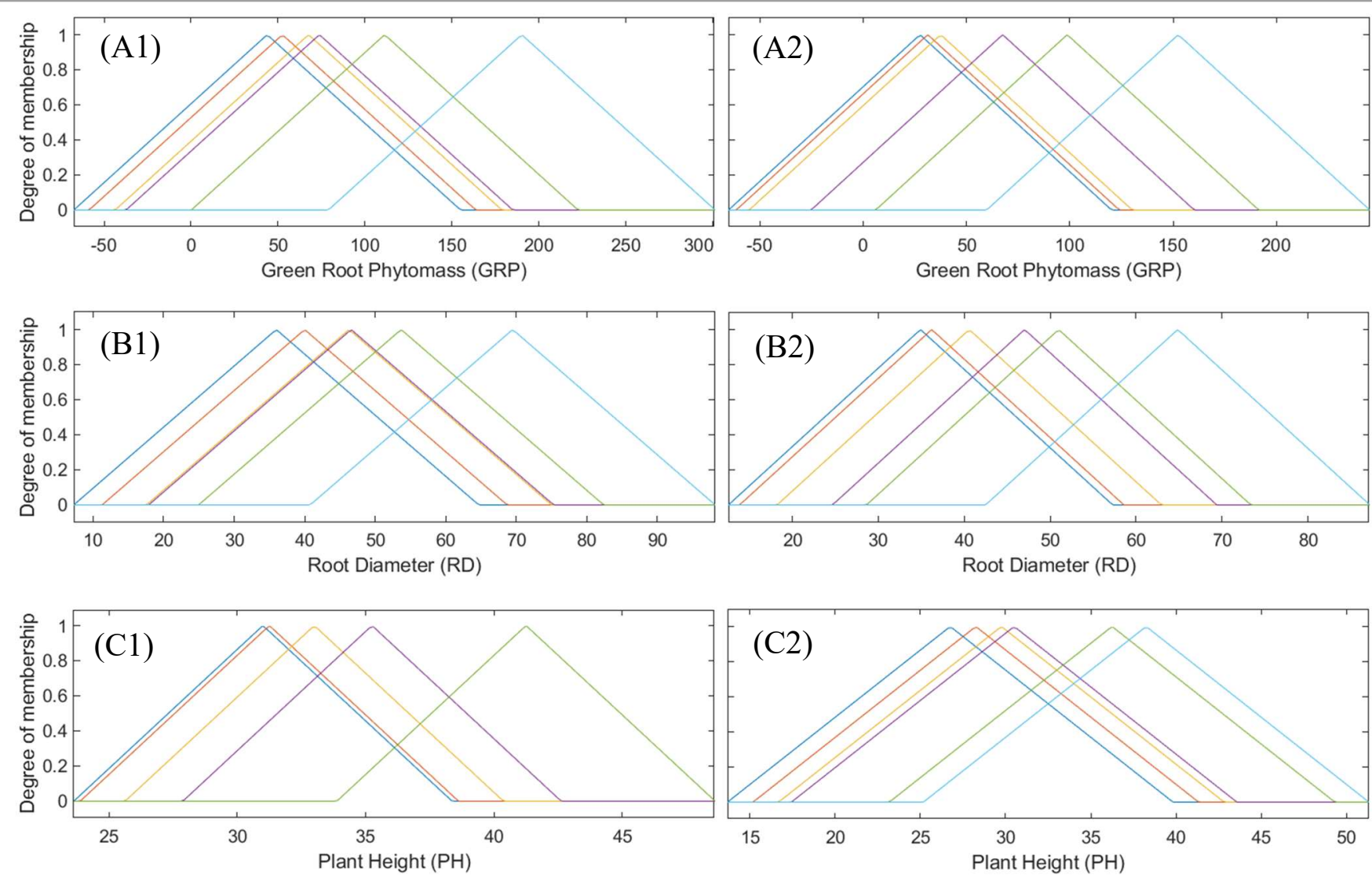

FIGURE 8. Membership functions of the fuzzy sets of the output variables (A) Green Root Phytomass, (B) Root Diameter; (C) Plant Height of beet submitted to different irrigations levels. Letters (A), (B) and (C) followed by number 1 represent variables for the Early Wonder cultivar model, while those followed by number 2 are associated with cultivar Itapuã 202.

The relationship that determines the FRBS was also proposed in line with the results of the averages obtained in the agronomic experiment conducted (Table 5). Its first three lines are explained below (while the others are interpreted similarly):

- If (Level is " $C_{1}$ ") then (the Green Root Phytomass is " $C_{1}$ "; Root Diameter is " $C_{2}$ "; Plant Height is " $C_{1}$ ");

- If (Level is " $C_{2}$ ") then (the Green Root Phytomass is " $C_{2}$ "; Root Diameter is " $C_{1}$ "; Plant Height is " $C_{2}$ ");

- If (Level is " $C_{3}$ ") then (the Green Root Phytomass is " $C_{4}$ "; Root Diameter is " $C_{3}$ "; Plant Height is " $C_{3}$ ");

TABLE 5. Fuzzy Rule-Based Systems of two models Early Wonder and Itapuã 202 cultivars.

\begin{tabular}{|c|c|c|c|c|}
\hline \multirow{2}{*}{ Cultivar } & \multirow{2}{*}{$\begin{array}{l}\text { Input Variables } \\
\text { Irrigation Level }\end{array}$} & \multicolumn{3}{|c|}{ Output Variables } \\
\hline & & Green Root Phytomass & Root Diameter & Plant Height \\
\hline \multirow{6}{*}{ Early Wonder } & $\mathrm{C} 1$ & $\mathrm{C} 1$ & $\mathrm{C} 2$ & $\mathrm{C} 1$ \\
\hline & $\mathrm{C} 2$ & $\mathrm{C} 2$ & $\mathrm{C} 1$ & $\mathrm{C} 2$ \\
\hline & $\mathrm{C} 3$ & $\mathrm{C} 4$ & $\mathrm{C} 3$ & $\mathrm{C} 3$ \\
\hline & $\mathrm{C} 4$ & $\mathrm{C} 3$ & $\mathrm{C} 4$ & $\mathrm{C} 3$ \\
\hline & $\mathrm{C} 5$ & $\mathrm{C} 5$ & $\mathrm{C} 5$ & $\mathrm{C} 4$ \\
\hline & C6 & C6 & C6 & $\mathrm{C} 5$ \\
\hline \multirow{6}{*}{ Itapuã 202} & $\mathrm{C} 1$ & $\mathrm{C} 1$ & $\mathrm{C} 2$ & $\mathrm{C} 2$ \\
\hline & $\mathrm{C} 2$ & $\mathrm{C} 2$ & $\mathrm{C} 1$ & $\mathrm{C} 1$ \\
\hline & C3 & $\mathrm{C} 3$ & C3 & $\mathrm{C} 3$ \\
\hline & $\mathrm{C} 4$ & $\mathrm{C} 4$ & $\mathrm{C} 4$ & $\mathrm{C} 4$ \\
\hline & $\mathrm{C} 5$ & $\mathrm{C} 5$ & $\mathrm{C} 5$ & $\mathrm{C} 5$ \\
\hline & C6 & C6 & C6 & C6 \\
\hline
\end{tabular}

RD, PH, and GRP were obtained using the Inference Method of Mamdani (Figures 9A, B, C, respectively). The curves were smooth and showed no abrupt changes around the averages. Moreover, the model performed excellently since the curve contained all points of treatment means. 

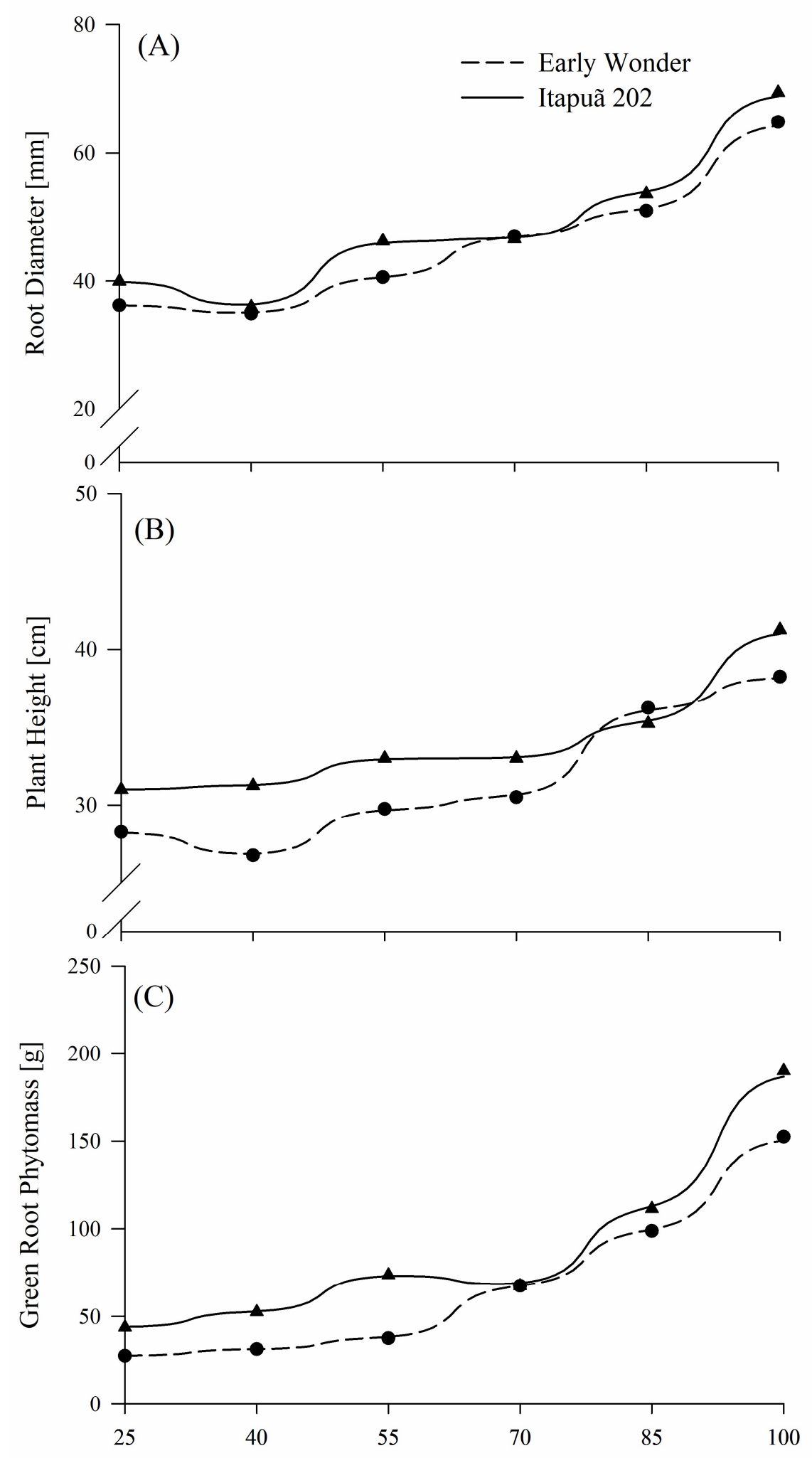

Irrigation level (\% ETc)

FIGURE 9. Fuzzy model fitting of means and curve of the Root Diameter (RD) (A), Height Plant (HP) (B), and Green Root Phytomass (GRP) (C) in function of different irrigation levels (\% ETc) for the Early Wonder and Itapuã 202 beet cultivars.

$\mathrm{RD}$ increased as the irrigation level was raised, which can be seen in the FRBS (Figure 9A). The cultivar Early Wonder had the highest RDs as a function of irrigation level. Similar behaviour was observed for the cultivar Itapuã 202, which had larger RDs for irrigation levels above $50 \%$.
The irrigation depth of $70 \%$ ETc increased GRP for cultivar Itapuã 202. In addition, better results are possible because the adaptation to the water deficit caused adaption in the physiology of the plant. Mbarki et al. (2018) observed that drought stress and excess salt cause reductions in production variables and plant physiological traits. 
The cultivar Early Wonder showed greater $\mathrm{PH}$ increases from the depth of $75 \%$ of ETc onwards, adapting better to the stress condition in these treatments (Figure 9B). The cultivar Itapuã 202 had similar behaviour, with PHs increasing from the irrigation depth of $75 \%$ of ETc onwards. As one of the main commercial characteristics of beets is $\mathrm{PH}$, proper irrigation management is needed for better plant growth. According to Mahmoud et al. (2018), beets are considered moderately sensitive to water deficit.

All water replacement rates applied to the beet cultivars had a similar effect on GRP (Figure 9C), but the cultivar Early Wonder developed more. Malik et al., (2018) and Perea et al. (2016) concluded that proper irrigation management is essential in determining beet yields. If irrigation does not meet water demands, plant development may be affected and, consequently, its GRP. The cultivar Early Wonder was better adapted to water deficit given its best development. The results show that both cultivars have a good adaptation for the pattern for commercialization. We observed increases in GRP from irrigation levels above 70\% of the ETc. Yonts et al. (2018) evaluated different irrigation management regimes in beet crops and observed that levels below $75 \%$ of the ETc significantly reduce yields.

All fuzzy models performed better than polynomial regression ones since they had coefficients of determination $\left(\mathrm{R}^{2}\right)$ higher than did polynomial ones $(0.54$ and 0.51 , respectively). RMSE and MAE errors were lower for the fuzzy models (Table 6) except for GRP. This variable had an MAE for the fuzzy model slightly higher than that of the polynomial one, denoting a better fit of the fuzzy models. Furthermore, for the same variable, the other two indices $\mathrm{R}^{2}$ and RMSE were better, showing the superiority of the fuzzy model compared to the polynomial one. By comparing the fuzzy and polynomial models, they showed mean RMSE values of 17.7 and 18.1, respectively, and mean MAE values of 13.3 and 13.5, respectively. These results, therefore, imply mean errors smaller for the fuzzy models.

TABLE 6. Results of the validation of fuzzy models of Root Diameter (RD), Height Plant (HP), Green Root Phytomass (GRP) for the Early Wonder and Itapuã 202 beet cultivars, and polynomial regression model (Polyn.), according to the coefficient of determination $\left(\mathrm{R}^{2}\right)$, the root mean square error (RMSE) and the mean absolute error (MAE).

\begin{tabular}{|c|c|c|c|c|c|c|}
\hline \multirow{2}{*}{ Cultivar } & \multirow{2}{*}{ Variables } & \multirow{2}{*}{ Model } & \multicolumn{3}{|c|}{ Indicators } & \multirow{2}{*}{$\begin{array}{c}\text { Regression } \\
\text { Equation }\end{array}$} \\
\hline & & & $\mathbf{R}^{2}$ & MAE & RMSE & \\
\hline \multirow{6}{*}{$\mathrm{C} 1$} & \multirow{2}{*}{ GRP } & Fuzzy & 0.57 & 32.1 & 42.9 & \multirow{2}{*}{$y=0.0349 x^{2}-2.648 x+95.99$} \\
\hline & & Polyn. & 0.54 & 33.1 & 44.5 & \\
\hline & \multirow{2}{*}{ RD } & Fuzzy & 0.49 & 9.53 & 11.1 & \multirow{2}{*}{$y=0.0068 x^{2}-0.473 x+47.00$} \\
\hline & & Polyn. & 0.46 & 9.64 & 11.4 & \\
\hline & \multirow{2}{*}{ PH } & Fuzzy & 0.60 & 2.30 & 2.85 & \multirow{2}{*}{$y=0.0024 x^{2}-0.185 x+34.53$} \\
\hline & & Polyn. & 0.56 & 2.53 & 2.97 & \\
\hline \multirow{6}{*}{$\mathrm{C} 2$} & \multirow{2}{*}{ GRP } & Fuzzy & 0.61 & 25.2 & 35.8 & \multirow{2}{*}{$y=0.0287 x^{2}-2.015 x+62.41$} \\
\hline & & Polyn. & 0.55 & 24.7 & 36.0 & \\
\hline & \multirow{2}{*}{ RD } & Fuzzy & 0.58 & 6.75 & 8.63 & \multirow{2}{*}{$y=0.0055 x^{2}-0.307 x+40.00$} \\
\hline & & Polyn. & 0.57 & 6.84 & 8.75 & \\
\hline & \multirow{2}{*}{$\mathbf{P H}$} & Fuzzy & 0.41 & 4.06 & 5.05 & \multirow{2}{*}{$y=0.0023 x^{2}-0.132 x+29.54$} \\
\hline & & Polyn. & 0.39 & 4.14 & 5.14 & \\
\hline
\end{tabular}

\section{CONCLUSIONS}

The fuzzy model allows us to evaluate the effect of water deficit on beet, which is sensitive to low water availability. The crop characteristics of beet analysed show a reduction as the percentage of ETc is decreased. Beet can achieve its maximum productive potential under an irrigation level of $100 \%$ ETc. The cultivar Itapuã 202 is more resistant to water stress than is the cultivar Early Wonder, showing greater green bulb weights.

The water deficit resulted in a reduction in the diameter and length of the bulb, directly affecting the crop yield in both cultivars. But specifically for the Cultivar Itapuã 202, according to the fuzzy system, the productivity of a water replacement from $75 \%$ ETc is equivalent to $100 \%$ ETc. Thus, using such a rate of $75 \%$ of ETc, the farmer will obtain the same productivity with the Cultivar Itapuã 202, configuring an optimization of the use of water.
As for validation, fuzzy models perform better than do polynomial regression ones when compared in terms of coefficient of determination $\left(\mathrm{R}^{2}\right)$, mean absolute error (MAE), and mean square error (RMSE). The fuzzy models still stand out in performance as the fuzzy curve contained the means of all treatments.

The fuzzy systems used in the present work explained rules implicit in the agronomic experiment, as well as showed a model that allowed an adequate comparison between the adopted cultivars.

\section{ACKNOWLEDGEMENTS}

This work was supported by the National Council for Scientific and Technological Development (CNPq) for the research productivity grants awarded (Process \#303923/2018-0 (FFP) and \#315228/2020-2 (LRAGF)). 


\section{REFERENCES}

Barros LC, Bassanezi RC, Lodwick WA (2017) A first course in fuzzy logic, fuzzy dynamical systems, and biomathematics: Theory and applications. SpringerVerlag. DOI: http://doi.org/10.1007/978-3-662-53324-6

Boso ACMR, Cremasco CP, Putti FF, Gabriel Filho LRA (2021a) Fuzzy modeling of the effects of different irrigation depths on the radish crop. Part I: Productivity analysis. Engenharia Agrícola 41(3):311-318. DOI: http://doi.org/10.1590/1809-4430-Eng.Agric.v41n3p311$318 / 2021$

Boso ACMR, Cremasco CP, Putti FF, Gabriel Filho LRA (2021b) Fuzzy modeling of the effects of different irrigation depths on the radish crop. Part II: Biometric variables analysis. Engenharia Agrícola 41(3):319-329. DOI: http://doi.org/10.1590/1809-4430-

Eng.Agric.v41n3p319-329/2021

Cremasco CP, Gabriel Filho LRA, Cataneo A (2010) Metodologia de determinação de funções de pertinência de controladores fuzzy para avaliação energética de empresas de avicultura de postura. Energia na Agricultura 25(3): 2139. DOI: http://doi.org/10.17224/EnergAgric.2010v25n1p21-39

Doorenbos J, Pruitt WO (1977). Crop Water Requirements. Rome, FAO. 179p. (FAO. Irrigation and Drainage Paper 24).

Elvanidi A, Katsoulas N, Bartzanas, T, Ferentinos KP, Kittas C. (2017) Crop water status assessment in controlled environment using crop reflectance and temperature measurements. Precision Agriculture 18(3): 332-349. DOI: http://doi.org/10.1007/s11119-016-9492-3

Gabriel Filho LRA, Cremasco CP, Putti FF, Chacur MGM (2011) Application of fuzzy logic for the evaluation of livestock slaughtering. Engenharia Agrícola 31(4):813825. DOI: http://doi.org/10.1590/S010069162011000400019

Gabriel Filho LRA, Pigatto GAS, Lourenzani AEBS (2015) Fuzzy rule-based system for evaluation of uncertainty in cassava chain. Engenharia Agrícola 35(2):350-367. DOI: http://doi.org/10.1590/1809-4430Eng.Agric.v35n2p350-367/2015

Gabriel Filho LRA, Putti FF, Cremasco CP, Bordin D, Chacur MGM, Gabriel LRA (2016) Software to assess beef cattle body mass through the fuzzy body mass index. Engenharia Agrícola 36(1):179-193. DOI: http://doi.org/10.1590/18094430-Eng.Agric.v36n1 p179-193/2016

Giusti E, Marsili-Libelli S (2015) A Fuzzy Decision Support System for irrigation and water conservation in agriculture. Environmental Modelling \& Software 63: 7386. DOI: http://doi.org/10.1016/j.envsoft.2014.09.020

Gobin A (2018) Weather related risks in Belgian arable agriculture. Agricultural Systems 159: 225-236. DOI: http://doi.org/10.1016/j.agsy.2017.06.009

Góes BC, Goes RJ, Cremasco CP, Gabriel Filho LRA (2021) Fuzzy modeling of vegetable straw cover crop productivity at different nitrogen doses. Modeling Earth Systems and Environment 7. DOI: http://doi.org/10.1007/s40808-021-01125-4
Hussain MI, Muscolo A, Farooq M, Ahmad W (2019) Sustainable use and management of non-conventional water resources for rehabilitation of marginal lands in arid and semiarid environments. Agricultural water management 221: 462-476. DOI: http://doi.org/10.1016/j.agwat.2019.04.014

Ilić ZS, Fallik E (2017) Light quality manipulation improves vegetable quality at harvest and postharvest: A review. Environmental and Experimental Botany 139: 7990. DOI: http://doi.org/10.1016/j.envexpbot.2017.04.006

Jalava M, Guillaume JH, Kummu M, Porkka M, Siebert S, Varis O (2016) Diet change and food loss reduction: What is their combined impact on global water use and scarcity? Earth's Future 4(3): 62-78. DOI: http://doi.org/10.1002/2015EF000327

Keller J, Bliesner RD (2000) Sprinkle and trickle irrigation. Cadwell, the Blackburn press. 652p.

Lauterbach M, Veranso-Libalah MC, Sukhorukov AP, Kadereit G (2019) Biogeography of the xerophytic genus Anabasis L. (Chenopodiaceae). Ecology and Evolution 9(6): 3539-3552. DOI: http://doi.org/10.1002/ece3.4987

Lesk C, Rowhani P, Ramankutty, N (2016) Influence of extreme weather disasters on global crop production. Nature 529 (7584): 84-87. DOI: http://doi.org/10.1038/nature16467

López-Mata E, Tarjuelo JM, Orengo-Valverde JJ, Pardo JJ, Domínguez, A (2019) Irrigation scheduling to maximize crop gross margin under limited water availability. Agricultural Water Management 223:105678. DOI: http://doi.org/10.1016/j.agwat.2019.06.013

Mahmoud ESA, Hassanin MA, Borham TI, Emara EI (2018) Tolerance of some sugar beet varieties to water stress. Agricultural Water Management 201: 144-151. DOI: http://doi.org/10.1016/j.agwat.2018.01.024

Maitah M, Řezbová H, Smutka L, Tomšík K (2016) European sugar production and its control in the world market. Sugar Technology 18(3): 236-241. DOI: http://doi.org/10.1007/s12355-016-0439-9

Malik A, Shakir AS, Naveedullah MJ, Khan ML, Khattak MS, Khan TA. (2018) Interactive effect of deficit irrigation and mulching on sugar beet productivity in Pakistan. Pakistan Journal of Botany 50(5): 1775-1783.

Mamdani EH, Assilian S (1975). An experiment in linguistic synthesis with a fuzzy logic controller. International journal of man-machine studies, 7(1): 1-13. DOI: http://doi.org/10.1016/S0020-7373(75)80002-2

Martínez MP, Cremasco CP, Gabriel Filho LRA, Braga Junior SS, Bednaski AV, Quevedo-Silva F, Correa CM, Silva D, Padgett RCML (2020) Fuzzy inference system to study the behavior of the green consumer facing the perception of greenwashing. Journal of Cleaner Production, 242: 116064. DOI: http://doi.org/10.1016/j.jclepro.2019.03.060

The MathWorks (2021) Fuzzy logic toolbox: user's guide (r2018a) 
Matulovic M, Putti FF, Cremasco CP, Gabriel Filho LRA (2021) Technology 4.0 with 0.0 costs: fuzzy model of lettuce productivity with magnetized water. Acta Scientiarum Agronomy 43. DOI: http://doi.org/10.4025/actasciagron.v43i1.51384

Maziero LP, Chacur MGM, Cremasco CP, Putti FF, Gabriel Filho LRA (2022) Fuzzy system for assessing bovine fertility according to semen characteristics. Livestock Science, 256: 104821. DOI: http://doi.org/10.1016/j.livsci.2022.104821

Mbarki S, Sytar O, Cerda A, Zivcak M, Rastogi A, He X, Brestic M (2018) Strategies to mitigate the salt stress effects on photosynthetic apparatus and productivity of crop plants. In Salinity Responses and Tolerance in Plants 1:85-136. DOI: http://doi.org/10.1007/978-3-319-75671-4_4

Mukherjee D (2017) Improved agronomic practices and input use efficiency for potato production under changing climate: improved practices for potato production. In: Sustainable potato production and the impact of climate change. IGI Global, p105-132. DOI:

http://doi.org/10.4018/978-1-5225-1715-3.ch005

Nuccio ML, Paul M, Bate NJ, Cohn J, Cutler SR. (2018). Where are the drought tolerant crops? An assessment of more than two decades of plant biotechnology effort in crop improvement. Plant science, 273: 110-119. DOI: http://doi.org/10.1016/j.plantsci.2018.01.020

Ostertagová E (2012) Modelling using Polynomial Regression. Procedia Engineering 48:500-506. DOI: http://doi.org/10.1016/j.proeng.2012.09.545

Perea RG, Poyato EC, Montesinos P, Morillo JG, Díaz JR. (2016) Influence of spatio temporal scales in crop water footprinting and water use management: Evidences from sugar beet production in Northern Spain. Journal of Cleaner Production 139: 1485-1495. DOI: http://doi.org/10.1016/j.jclepro.2016.09.017

Pereira DF, Bighi CA, Gabriel Filho LRA, Cremasco CPC (2008) Sistema fuzzy para estimativa do bem-estar de matrizes pesadas. Engenharia Agrícola 28(4):624-633. DOI: http://doi.org/10.1590/S0100-69162008000400002

Prato $T$ (2012) Increasing resilience of natural protected areas to future climate change: A fuzzy adaptive management approach. Ecological Modelling 242: 46-53. DOI: http://doi.org/10.1016/j.ecolmodel.2012.05.014

Putti FF, Gabriel Filho LRA, Silva AO, Ludwig R, Cremasco CP (2014) Fuzzy logic to evaluate vitality of Catasetum fimbiratum species (Orchidacea). Irriga 19(3):405-413. DOI:

http://doi.org/10.15809/irriga.2014v19n3p405

Putti FF, Gabriel Filho LRA, Cremasco CP, Klar AE (2015) Fuzzy modeling of development of sheets number in different irrigation levels of irrigated lettuce with magnetically treated water. In: 7th International Conference on Fuzzy Computation Theory and Applications. Setúbal, Science and Technology Publications, Proceedings... DOI: http://doi.org/10.5220/0005599701620169
Putti FF, Gabriel Filho LRA, Cremasco CP, Bonini Neto A, Bonini CSB, Reis AR (2017a) A Fuzzy mathematical model to estimate the effects of global warming on the vitality of Laelia purpurata orchids. Mathematical Biosciences 288:124-129. DOI: http://doi.org/10.1016/j.mbs.2017.03.005

Putti FF, Kummer ACB, Grassi Filho H, Gabriel Filho LRA, Cremasco CP (2017b) Fuzzy modeling on wheat productivity under different doses of sludge and sewage effluent. Engenharia Agrícola 37(6):1103-1115. DOI: http://doi.org/10.1590/1809-4430-eng.agric.v37n6p1103$1115 / 2017$

Putti FF, Lanza MH, Grassi Filho H, Cremasco CP, Souza AV, Gabriel Filho LRA (2021) Fuzzy modeling in orange production under different doses of sewage sludge and wastewater. Engenharia Agrícola, 41(2):204-214. DOI: http://doi.org/10.1590/1809-4430-eng.agric.v41n2p204$214 / 2021$

Ringle CM, Silva D, Bido D (2014) Modelagem de equações estruturais com utilização do smartpls. Revista Brasileira de Marketing 13(2):56-73. DOI: http://doi.org/10.5585/remark.v13i2.2717

Silva AO, Silva EFF, Bassoi LH, Klar AE (2015) Desenvolvimento de cultivares de beterraba sob diferentes tensões da água no solo. Horticultura Brasileira 33(1):1218. DOI: http://doi.org/10.1590/S0102-053620150000100003

Viais Neto DS, Cremasco CP, Bordin D, Putti FF, Silva Junior JF, Gabriel Filho LRA (2019a) Fuzzy modeling of the effects of irrigation and water salinity in harvest point of tomato crop. Part I: description of the method.

Engenharia Agrícola 39(3):294-304. DOI:

http://doi.org/10.1590/1809-4430-eng.agric.v39n3p294$304 / 2019$

Viais Neto DS, Cremasco CP, Bordin D, Putti FF, Silva Junior JF, Gabriel Filho LRA (2019b) Fuzzy modeling of the effects of irrigation and water salinity in harvest point of tomato crop. Part II: application and interpretation. Engenharia Agrícola 39(3):305-14. DOI: http://doi.org/10.1590/1809-4430-eng.agric.v39n3p305$314 / 2019$

Waongo M, Laux P, Traoré SB, Sanon M, Kunstmann H (2014) A crop model and fuzzy rule based approach for optimizing maize planting dates in Burkina Faso, West Africa. Journal of Applied Meteorology and Climatology 53(3): 598-613. DOI: http://doi.org/10.1175/JAMC-D-130116.1

Yonts CD, Haghverdi A, Reichert DL, Irmak S (2018) Deficit irrigation and surface residue cover effects on dry bean yield, in-season soil water content and irrigation water use efficiency in western Nebraska high plains. Agricultural water management 199: 138-147. DOI: http://doi.org/10.1016/j.agwat.2017.12.024 